\title{
PENERAPAN PENILAIAN AUTENTIK BERDASARKAN KURIKULUM 2013 PADA KOMPETENSI KEAHLIAN TEKNIK GAMBAR BANGUNAN DI SMK NEGERI WILAYAH DKI JAKARTA
}

\author{
Dinar Rosmawati, ${ }^{1}$ Tuti Iriani ${ }^{2}$, Daryati ${ }^{3}$ \\ ${ }^{1}$ Alumni Pendidikan Teknik Bangunan FT UNJ,Jakarta, Indonesia. \\ 2 Pendidikan Teknik Bangunan, FT UNJ, Jakarta, Indonesia \\ ${ }^{3}$ Pendidikan Teknik Bangunan, FT UNJ, Jakarta, Indonesia \\ *Corresponding author: dinar.rosmawati@gmail.com
}

\begin{abstract}
This study aims to get information and the problem which is face by teacher about applied of authentic assessment base on curriculum 2013 in The Drawing of Buildings Engineering Program Expertise at 1 Vocational High School of Jakarta, 26 Vocational High School of Jakarta, and 35 Vocational High School of Jakarta.

This study used survey method with data collection using structures interview techniques to get the information and the problem which is face by teacher about applied of authentic assessment base on curriculum 2013.

The results of this study shown that the applied of authentic assessment base on curriculum 2013 in The Drawing of Buildings Engineering Program Expertise at Vocational High School Area of DKI Jakarta not going well. Because, just $29 \%$ respondents who have understanding the true of authentic assessment. RPP preparation only performed by $71 \%$ respondents and $100 \%$ respondents not preparation instruments realm of attitudes and skill but only preparation instrument of knowledge. However, almost all the teacher 95\% respondents not conduction an analysis of the quality assessment instrument realm of knowledge that has been made. The follow up program given by $86 \%$ respondents for the students in the form of remedial activities. For the results of this study shown too that $86 \%$ respondents states find the problem in the applied of authentic assessment.
\end{abstract}

Keywords: Authentic Assessment, Curriculum 2013, Drawing of Buildings Engineering Program Expertise 


\section{PENDAHULUAN}

Sejalan dengan pelaksanaan program pendidikan di Indonesia yang menuntut perkembangan ilmu pengetahuan dan teknologi, membuat pemerintah harus menyesuaikan kurikulum agar dapat memenuhi kebutuhan dan tuntutan di masyarakat terhadap dunia pendidikan. Perubahan kurikulum tersebut membuat Kurikulum Tingkat Satuan Pendidikan (KTSP) berubah menjadi Kurikulum 2013 yang dalam pelaksanaanya diharapkan peserta didik mampu dibekali kemampuan pada ranah sikap, pengetahuan, dan keterampilan, serta menjadi pribadi yang beriman, produktif, kreatif, dan mampu berkontribusi pada kehidupan bermasyarakat (Kunandar, 2013:16).

Di dalam Permendikbud Nomor 104 Tahun 2014 terdapat beberapa kriteria penilaian. Salah satu kriteria penilaian yang menjadi penekanan dalam kurikulum 2013 adalah sistem penilaian autentik (authentic assessment). Sistem penilaian tersebut dianggap baik, karena dapat mendorong pendidik untuk mengajar lebih baik serta peserta didik untuk belajar lebih baik (Mardapi, 2012:4). Sementara itu, di dalam Permendikbud Nomor 66 Tahun 2013 menyebutkan bahwa penilaian yang baik harus dilakukan sesuai dengan prinsip penilaian yakni objektif, terpadu, ekonomis, transparan, edukatif, dan akuntabel.

Penilaian autentik merupakan suatu proses pengumpulan, pelaporan, dan penggunaan informasi tentang hasil belajar peserta didik dengan menerapkan prinsipprinsip penilaian, pelaksanaan berkelanjutan, bukti- bukti autentik, akurat, dan konsisten (Pusat Kurikulum, 2009). Kunandar (2013:36) mengemukakan bahwa penilaian autentik ini mempertegas adanya pergeseran dalam melakukan penilaian, yakni dari penilaian melalui tes (mengukur kompetensi pengetahuan berdasarkan hasil saja), menuju penilaian autentik (mengukur kompetensi sikap, pengetahuan, dan keterampilan berdasarkan proses dan hasil).

Menurut Nurgiyantoro (2011:23) tujuan dari penilaian autentik adalah untuk mengukur berbagai keterampilan peserta didik dalam berbagai konteks yang mencerminkan situasi di dunia nyata dimana keterampilan-keterampilan tersebut digunakan.

Berdasarkan hasil penelitian Enggarwati (2015) menunjukkan bahwa pendidik mengalami kesulitan dalam penerapan penilaian autentik karena pemahaman pendidik tentang penilaian autentik yang masih kurang. Sementara itu, hasil penelitian Pantiwati (2013) menyatakan bahwa tes tulis bentuk objektif mendominasi instrumen penilaian hasil belajar peserta didik karena dianggap teknik yang mudah dilaksanakan dan cepat dalam pengoreksian. Masalah tersebut serupa dengan hasil observasi pada salah satu SMK Negeri di wilayah DKI Jakarta yang menunjukkan bahwa pemahaman pendidik tentang penilaian autentik yang masih kurang serta umumnya pendidik hanya memfokuskan penilaian pada ranah kognitif peserta didik. Mengacu pada 
permasalahan tersebut, maka perlu dilaksanakan penelitian di beberapa SMK Negeri yang terdapat di wilayah DKI Jakarta khususnya kepada pendidik kompetensi keahlian Teknik Gambar Bangunan untuk lebih mengetahui dan melihat bagaimana penerapan penilaian autentik yang dilakukan kepada peserta didik dalam proses pembelajaran.

\section{METODE PENELITIAN}

Metode dalam penelitian ini menggunakan metode survei dengan pengumpulan data menggunakan teknik wawancara terstruktur yang digunakan untuk mengetahui penerapan dalam penilaian autentik berdasarkan kurikulum 2013 serta kendala yang dihadapi dalam melakukan penilaian tersebut.

Penelitian dilaksanakan pada tanggal 2 Mei 2016 s/d 20 Mei 2016 di beberapa SMK Negeri di DKI Jakarta yang memiliki kompetensi keahlian Teknik Gambar Bangunan. Adapun SMK Negeri yang termasuk dalam penelitian yaitu (1) SMK Negeri 26; (2) SMK Negeri 1; (3) SMK Negeri 35.

Populasi dalam penelitian ini berjumlah 30 orang dengan rincian seperti pada tabel 1.

Tabel 1. Populasi Penelitian

\begin{tabular}{|c|l|c|c|c|}
\hline No & Nama Sekolah & Pendidik & $\begin{array}{c}\text { Kepala Wakil } \\
\text { Bidana Kurikulum }\end{array}$ & Peserta Didik \\
\hline 1 & SMK Negeri 1 & 5 & 1 & 2 \\
\hline 2 & SMK Negeri 26 & 10 & 1 & 2 \\
\hline 3 & SMK Negeri 35 & 6 & 1 & 2 \\
\hline \multicolumn{2}{|c|}{ Jumlah } & \multicolumn{3}{|c|}{$\mathbf{3 0}$} \\
\hline
\end{tabular}

Sampel dalam penelitian ini menggunakan sampel jenuh atau sensus dimana seluruh anggota populasi sebanyak 30 orang dijadikan sebagai sampel penelitian. Instrumen dalam penelitian ini menggunakan pedoman wawancara dengan kisi-kisi seperti pada tabel 2.

Tabel 2. Kisi-kisi Pedoman Wawancara

\begin{tabular}{|c|l|c|c|}
\hline No. & \multicolumn{1}{|c|}{ Indikator } & Nomor Butir & Jumlah Butir \\
\hline 1. & Pemahaman penilaian autentik & 1 & 1 \\
\hline 2. & Prosedur penilaian autentik & 2 dan 7 & 2 \\
\hline 3. & Pelaksanaan penilaian autentik & 3 & 1 \\
\hline 4. & Teknik penilaian yang digunakan & 4,5, dan 6 & 3 \\
\hline 5. & Program tindak lanjut & 8 & 1 \\
\hline 6. & Kendala dalam penilaian autentik & 9 & 1 \\
\hline \multicolumn{3}{|c|}{ Jumlah } & 9 \\
\hline
\end{tabular}


Teknik analisis data pada penelitian ini menggunakan teknik analisis deskriptif kuantitatif yaitu berupa paparan sederhana menggunakan presentase dari tiap- tiap indikator.

\section{HASIL DAN PEMBAHASAN}

\section{Penerapan Penilaian Autentik Berdasarkan Indikator}

Secara keseluruhan data
penerapan penilaian autentik yang
dilakukan pendidik berdasarkan hasil
wawancara terdapat pada tabel 3 .

Tabel 3. Penerapan Penilaian Autentik Berdasarkan Indikator

\begin{tabular}{|c|l|c|c|c|c|}
\hline \multirow{2}{*}{ No } & \multirow{2}{*}{$\begin{array}{l}\text { Indikator Penerapan Penilaian } \\
\text { Autentik }\end{array}$} & \multicolumn{2}{c|}{$\begin{array}{c}\text { Frekuensi } \\
\text { Jawaban }\end{array}$} & \multicolumn{2}{c|}{$\begin{array}{c}\text { Prosentase } \\
\text { Jawaban }\end{array}$} \\
\cline { 3 - 6 } & \multicolumn{1}{|c|}{ Ya } & Tidak & Ya & Tidak \\
\hline 1. & Pemahaman penilaian autentik & 21 & - & $100 \%$ & - \\
\hline 2. & Prosedur penilaian autentik & 21 & - & $100 \%$ & - \\
\hline 3. & Pelaksanaan penilaian autentik & 21 & - & $100 \%$ & - \\
\hline 4. & Program tindak lanjut & 18 & 3 & $86 \%$ & $14 \%$ \\
\hline 5. & $\begin{array}{l}\text { Kendala dalam penerapan penilaian } \\
\text { autentik }\end{array}$ & 18 & 3 & $86 \%$ & $14 \%$ \\
\hline
\end{tabular}

Data pada tabel tersebut akan dijelaskan secara lebih rinci sebagai berikut:

1. Pemahaman Penilaian Autentik Berdasarkan Kurikulum 2013
Dari hasil wawancara dengan pertanyaan mengenai pemahaman penilaian autentik berdasarkan kurikulum 2013 menghasilkan keterangan seperti pada tabel 4

Tabel 4. Pemahaman Penilaian Autentik

\begin{tabular}{|c|l|c|c|}
\hline No & \multicolumn{1}{|c|}{ Keterangan Responden } & Frekuensi & Prosentase \\
\hline 1. & $\begin{array}{l}\text { Penilaian autentik merupakan penilaian yang } \\
\text { mencakup ke dalam tiga ranah } \\
\text { yaitu sikap, pengetahuan, dan keterampilan } \\
\text { peserta didik. }\end{array}$ & 8 responden & $38 \%$ \\
\hline 2 & $\begin{array}{l}\text { Penilaian autentik merupakan penilaian yang } \\
\text { lengkap karena membutuhkan 11 komponen } \\
\text { penilaian yang meliputi ranah sikap, pengetahuan, } \\
\text { dan keterampilan peserta didik. }\end{array}$ & 6 responden & $29 \%$ \\
\hline 3 & $\begin{array}{l}\text { Penilaian autentik hanya mengutamakan sikap dari } \\
\text { peserta didik dalam melakukan penilaian. }\end{array}$ & 2 responden & $9 \%$ \\
\hline 4 & $\begin{array}{l}\text { Penilaian autentik merupakan penilaian yang sulit } \\
\text { karena terlalu banyak komponen yang harus dinilai } \\
\text { oleh pendidik kepada peserta didik. }\end{array}$ & 5 responden & $24 \%$ \\
\hline
\end{tabular}


Berdasarkan tabel tersebut dapat disimpulkan bahwa pemahaman pendidik terhadap penilaian autentik masih kurang, karena hanya $29 \%$ dari 21 responden yang mengetahui penilaian autentik dengan benar.

\section{Tahapan atau Prosedur}

\section{Penerapan Penilaian Autentik}

dalam penerapan penilaian autentik dapat dilihat dari (1) penentuan tujuan penilaian berupa penyusunan RPP oleh pendidik; (2) penyusunan instrumen penilaian ranah sikap, pengetahuan, dan keterampilan; (3) analisis terhadap kualitas instrumen penilaian yang dibuat.VDari hasil wawancara dengan pertanyaan mengenai prosedur yang harus dipenuhi dalam melakukan penilaian autentik dapat dijelaskan sebagai berikut:

\subsection{Penyusunan RPP}

\section{Tabel 5. Penyusunan RPP}

\begin{tabular}{|c|l|c|c|}
\hline No & \multicolumn{1}{|c|}{ Keterangan Responden } & Frekuensi & Prosentase \\
\hline 1. & $\begin{array}{l}\text { Penyusunan RPP dilakukan untuk dijadikan } \\
\text { pedoman dalam melakukan proses pembelajaran. }\end{array}$ & $\begin{array}{c}12 \\
\text { responden }\end{array}$ & $57 \%$ \\
\hline 2. & $\begin{array}{l}\text { Penyusunan RPP dilakukan untuk mengetahui } \\
\text { kompetensi yang akan dicapai dalam setiap } \\
\text { nembelaiaran }\end{array}$ & 3 responden & $14 \%$ \\
\hline 3. & $\begin{array}{l}\text { Penyusunan RPP tidak dilakukan karena terdapat } \\
\text { keterbatasan waktu yang ada, sehingga untuk } \\
\text { melakukan penyusunan RPP menjadi tidak } \\
\text { sempat untuk dilakukan. }\end{array}$ & 6 responden & $29 \%$ \\
\hline
\end{tabular}

Berdasarkan tabel tersebut dapat diambil kesimpulan bahwa hanya $71 \%$ dari 21 responden yang menyatakan telah melakukan penyusunan RPP.

Tabel 6. Penyusunan Instrumen Penilaian Ranah Sikap, Pengetahuan, dan Keterampilan

\begin{tabular}{|c|l|c|c|}
\hline No & \multicolumn{1}{|c|}{ Keterangan Responden } & Frekuensi & Prosentase \\
\hline 1. & $\begin{array}{l}\text { Tidak melakukan penyusunan instrumen ranah } \\
\text { sikap karena sikap peserta didik dapat dinilai } \\
\text { berdasarkan pengamatan secara langsung. }\end{array}$ & $\begin{array}{c}17 \\
\text { responden }\end{array}$ & $81 \%$ \\
\hline 2. & $\begin{array}{l}\text { Tidak melakukan penyusunan instrumen ranah } \\
\text { sikap karena menilai sikap peserta didik } \\
\text { herdasarkan ahensi kehadiran intrumen ranah }\end{array}$ & 3 responden & $14 \%$ \\
\hline 3. & $\begin{array}{l}\text { Tidak melakukan penyusunan inap karena tidak ada waktu dalam melakukan } \\
\text { sikap } \\
\text { nenvusunan }\end{array}$ & $5 \%$ \\
\hline
\end{tabular}




\begin{tabular}{|c|c|c|c|}
\hline No & Keterangan Responden & Frekuensi & Prosentase \\
\hline 4. & $\begin{array}{l}\text { Melakukan penyusunan instrumen ranah } \\
\text { pengetahuan karena instrumen tersebut akan } \\
\text { dijadikan alat untuk mengukur kemampuan } \\
\text { peserta didik pada saat UTS atau UAS. }\end{array}$ & $\begin{array}{c}11 \\
\text { responden }\end{array}$ & $52 \%$ \\
\hline 5. & $\begin{array}{lll}\text { Melakukan penyusunan instrumen ranah } \\
\text { pengetahuan karena hal tersebut sudah biasa } \\
\text { dilakukan jadi tidak ditemukan kesulitan. }\end{array}$ & 6 responden & $29 \%$ \\
\hline 6. & 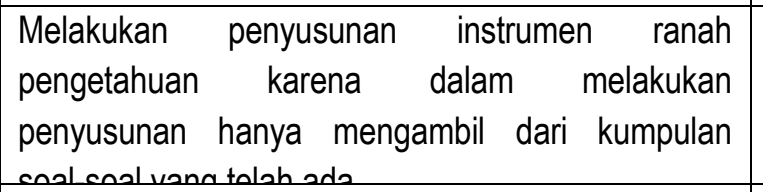 & 4 responden & $19 \%$ \\
\hline 7. & $\begin{array}{l}\text { Tidak melakukan penyusunan instrumen ranah } \\
\text { keterampilan karena keterampilan peserta didik } \\
\text { dinilai dengan melihat bagaimana cara peserta } \\
\text { didik tersebut dapat menyelesaikan soal yang } \\
\text { diberikan. }\end{array}$ & $\begin{array}{c}14 \\
\text { responden }\end{array}$ & $66 \%$ \\
\hline 8. & $\begin{array}{l}\text { Tidak melakukan penyusunan instrumen ranah } \\
\text { keterampilan karena keterampilan peserta didik } \\
\text { tidak dinilai berdasarkan aspek melainkan dinilai } \\
\text { secara keseluruhan pada saat praktek } \\
\text { berlangsung }\end{array}$ & 5 responden & $24 \%$ \\
\hline 9. & $\begin{array}{l}\text { Tidak melakukan penyusunan instrumen ranah } \\
\text { keterampilan karena keterampilan peserta didik } \\
\text { dinilai dengan melihat seberapa cepat peserta } \\
\text { didik tersebut menyelesaikan tugas yang }\end{array}$ & 1 responden & $5 \%$ \\
\hline 10. & $\begin{array}{l}\text { Tidak melakukan penyusunan instrumen ranah } \\
\text { keterampilan karena keterampilan peserta didik } \\
\text { dinilai dengan melihat peserta didik tersebut } \\
\text { mampu mempresentasikan bahasan yang diberikan } \\
\text { pendidik. }\end{array}$ & 1 responden & $5 \%$ \\
\hline
\end{tabular}

Berdasarkan tabel tersebut dapat disimpulkan bahwa pada umumnya pendidik tidak melakukan penyusunan instrumen ranah sikap dan keterampilan, melainkan hanya melakukan penyusunan instrumen ranah pengetahuan sebagai bahan untuk penyusunan tes. Dari hasi tersebut maka penilaian hanya difokuskan pada ranah pengetahuan saja.

\subsection{Analisis Kualitas Instrumen}

\section{Penilaian}

Keterangan dari responden mengenai analisis kualitas instrumen penilaian terdapat pada tabel 7 . 
Tabel 7. Analisis Kualitas Instrumen Penilaian

\begin{tabular}{|c|c|c|c|}
\hline No & \multicolumn{1}{|c|}{ Keterangan Responden } & Frekuensi & Prosentase \\
\hline 1. & $\begin{array}{l}\text { Melakukan analisis kualitas instrumen penilaian } \\
\text { yang dibuat pada akhir dari ulangan yang telah } \\
\text { diberikan untuk meninjau soal mana yang banyak } \\
\text { dijawab benar atau salah oleh peserta didik. }\end{array}$ & 1 responden & $5 \%$ \\
\hline
\end{tabular}

Berdasarkan tabel tersebut dapat diambil kesimpulan bahwa hampir semua pendidik 95\% dari 21 responden menyatakan tidak melakukan analisis terhadap kualitas dari instrumen penilaian yang dibuat.

\section{Pelaksanaan Penilaian Autentik Berdasarkan Kurikulum 2013}

Dari hasil wawancara melalui pertanyaan mengenai pelaksanaan penilaian autentik menunjukkan bahwa $100 \%$ dari 21 responden menyatakan telah menerapkan pada mata pelajaran yang diajarkannya. Adapun teknik penilaian yang digunakan pendidik dalam tiap ranah akan dijelaskan secara lebih rinci sebagai berikut:

\subsection{Penilaian Ranah Sikap}

Dari kelima teknik penilaian ranah sikap observasi, penilaian diri, penilaian teman sebaya, jurnal, dan wawancaraumumnya pendidik hanya melakukan penilaian ranah sikap dengan cara observasi atau pengamatan.

\subsection{Penilaian Ranah Pengetahuan}

Dari ketiga teknik penilaian ranah pengetahuan tes tulis, tes lisan, dan penugasan hampir semua pendidik memilih bentuk tes tertulis dan penugasan sebagai cara dalam melakukan penilaian ranah pengetahuan, dan hanya beberapa pendidik yang memilih bentuk tes lisan.

\subsection{Penilaian Ranah Keterampilan}

Dari ketiga teknik penilaian ranah keterampilan unjuk kerja, proyek, dan portofolio umumnya pendidik hanya melakukan penilaian ranah keterampilan dengan cara unjuk kerja.

\section{Program Tindak Lanjut Hasil Penilaian}

Dari hasil wawancara melalui pertanyaan mengenai pelaksanaan program tindak lanjut terhadap hasil penilaian autentik yang dilakukan oleh pendidik sebagai responden menghasilkan keterangan seperti pada tabel 8 . 
Tabel 8. Program Tindak Lanjut Terhadap Hasil Penilaian Autentik

\begin{tabular}{|l|l|c|c|}
\hline No & \multicolumn{1}{|c|}{ Keterangan Responden } & Frekuensi & Prosentase \\
\hline 1. & $\begin{array}{l}\text { Memberikan program tindak lanjut kepada } \\
\text { peserta didik berupa kegiatan remedial dengan } \\
\text { memberikan kembali soal yang telah dikerjakan } \\
\text { sebelumnya sampai peserta didik tersebut } \\
\text { mampu mencapai nilai minimum yang telah } \\
\text { ditentukan sekolah. }\end{array}$ & \multicolumn{1}{c|}{$\begin{array}{c}18 \\
\text { responden }\end{array}$} & $86 \%$ \\
\hline 2. & $\begin{array}{l}\text { Tidak memberikan program tindak lanjut berupa } \\
\text { kegiatan remedial atau kegiatan pengayaan, } \\
\text { kegiatan remedial dirasa tidak diperlukan karena } \\
\text { pada nilai akhir peserta didik pasti tetap akan } \\
\text { menjadi tuntas dan mencapai KKM sehingga tidak } \\
\text { perlu membuang waktu untuk melaksanakan } \\
\text { kegiatan remedial tersebut. }\end{array}$ & 2 responden & \\
\hline 3. & $\begin{array}{l}\text { Tidak memberikan program tindak lanjut berupa } \\
\text { kegiatan remedial atau kegiatan pengayaan, } \\
\text { kegiatan remedial dirasa tidak diperlukan karena } \\
\text { jika dari awal peserta didik mengetahui akan } \\
\text { diadakan kegiatan remedial maka pada saat } \\
\text { ulangan berlangsung peserta didik tidak } \\
\text { mengerjakan dengan sungguh-sungguh karena } \\
\text { tahu nantinya pada nilai akhir pasti akan } \\
\text { dituntaskan. }\end{array}$ & 1 responden & \\
\hline
\end{tabular}

Berdasarkan tabel tersebut dapat disimpulkan bahwa $86 \%$ dari 21 responden memberikan program tindak lanjut kepada peserta didik dari hasil penilaian autentik berupa kegiatan remedial. Namun, dari hasil tersebut $14 \%$ dari 21 responden menyatakan tidak melakukan program tindak lanjut .

\section{Kendala Penerapan}

Penilaian Autentik Kurikulum 2013

Dari hasil wawancara melalui pertanyaan mengenai kendala dalam penerapan penilaian autentik yang dihadapi oleh pendidik sebagai responden menghasilkan keterangan seperti pada tabel 9 . 
Tabel 9. Kendala Penerapan Penilaian Autentik Kurikulum 2013

\begin{tabular}{|c|l|c|c|}
\hline No & \multicolumn{1}{|c|}{ Keterangan Responden } & Frekuensi & Prosentase \\
\hline 1. & $\begin{array}{l}\text { Ditemukan kendala dalam penerapan penilaian autentik } \\
\text { yaitu terdapat pada kurangnya waktu dalam melakukan } \\
\text { penilaian, karena pada penilaian autentik membutuhkan } \\
\text { banyak komponen atau aspek yang harus dinilai oleh } \\
\text { pendidik kepada peserta didik. }\end{array}$ & 9 responden & $43 \%$ \\
\hline 2. & $\begin{array}{l}\text { Ditemukan kendala dalam penerapan penilaian autentik } \\
\text { yaitu terdapat pada kemampuan yang dimiliki oleh } \\
\text { peserta didik yang berbeda-beda. }\end{array}$ & 7 responden \\
\hline 3. & $\begin{array}{l}\text { Ditemukan kendala dalam penerapan penilaian autentik } \\
\text { yaitu terdapat pada kurangnya sarana dan prasarana } \\
\text { pang memfasilitasi khususnya untuk melakukan }\end{array}$ & 2 responden & $33 \%$ \\
\hline 4. & $\begin{array}{l}\text { Tidak ditemukan kendala dalam penerapan penilaian } \\
\text { autentik karena dalam melakukan penilaian kepada } \\
\text { peserta didik sudah biasa dilakukan. }\end{array}$ & 3 responden & $10 \%$ \\
\hline
\end{tabular}

Berdasarkan tabel tersebut dapat disimpulkan bahwa $86 \%$ dari 21 responden menyatakan menemukan kendala dalam penerapan penilaian autentik. Namun, dari hasil tersebut juga ditemukan bahwa $14 \%$ dari 21 responden yang tidak mengalami kendala dalam penerapan penilaian autentik.

\section{HASIL DAN PEMBAHASAN}

Dari hasil wawancara dengan pendidik sebagai responden penelitian tentang penerapan penilaian autentik berdasarkan kurikulum 2013 pada kompetensi keahlian Teknik Gambar Bangunan di SMK Negeri wilayah DKI Jakarta, menunjukkan bahwa pendidik belum sepenuhnya memahami tentang penilaian autentik. Hal ini sesuai dengan hasil penelitian Enggarwati(2015) yang menyatakan bahwa pendidik mengalami kesulitan dalam penerapan penilaian autentik karena pemahaman pendidik tentang penilaian autentik yang masih kurang. Kurangnya pemahaman dari pendidik menjadikan $100 \%$ dari 21 responden tidak melakukan penyusunan instrumen penilaian pada ranah sikap dan keterampilan serta hanya $71 \%$ dari 21 responden yang melakukan penyusunan RPP sebagai upaya dalam memenuhi prosedur sebelum melakukan penilaian. Sementara itu, ditemukan pula sebanyak 95\% dari 21 responden yang tidak melakukan analisis terhadap instrumen penilaian yang dibuat dan hanya $86 \%$ dari 21 responden yang melakukan program tindak lanjut terhadap hasil penilaian autentik. Dengan kondisi tersebut $86 \%$ dari 21 responden menyatakan menemukan kendala dalam 
penerapan penilaian autentik dengan kendala yang dihadapi berbeda-beda.

Penilaian autentik yang dipahami oleh pendidik merupakan penilaian yang mencakup ke dalam ranah sikap, pengetahuan, dan keterampilan peserta didik. Hal tersebut sesuai dengan yang terdapat pada Permendikbud Nomor104 (2014) yang menyatakan bahwa penilaian autentik merupakan bentuk penilaian yang menghendaki peserta didik menampilkan sikap, menggunakan pengetahuan dan keterampilan yang diperoleh dari pembelajaran. Namun, bila dilihat secara lebih mendalam tidak terdapat responden yang menyatakan bahwa dalam penerapan penilaian autentik perlu dilakukan secara berkelanjutan dan bukan hanya menilai hasil melainkan prosesnya pun turut dalam penilaian. Hal tersebut bertentangan dengan yang terdapat pada Permendikbud Nomor 66 (2013) yang menyatakan bahwa penilaian autentik merupakan penilaian yang dilakukan secara komprehensif untuk menilai mulai dari masukan (input), proses, dan keluaran (output) pembelajaran.

Dari pemahaman tersebut berhubungan dengan prosedur dalam penerapan penilaian yang mencakup penentuan tujuan yang dapat dilihat dari penyusunan RPP yang dilakukan pendidik, penyusunan instrumen penilaian, analisis terhadap kualitas instrumen penilaian, serta program tindak lanjut hasil penilaian (Majid, 2015:29). Hasil wawancara menunjukkan bahwa hanya $71 \%$ dari 21 responden yang melakukan penyusunan RPP. Sementara itu, $100 \%$ dari 21 responden menyatakan tidak melakukan penyusunan instrumen penilaian ranah sikap dan keterampilan. Penyusunan RPP dan instrumen penilaian yang tidak dilakukan pendidik bertentangan dengan pernyataan dari Pusat Kurikulum (2009) yang menyatakan bahwa dalam penilaian autentik juga dibutuhkan buktibukti secara autentik.

Ketiadaan instrumen ranah sikap dan keterampilan menjadi tidak sesuai dengan prinsip penilaian yang terdapat pada Permendikbud Nomor 66 (2013) yaitu objektif yang berarti bahwa penilaian harus didasarkan pada prosedur dan kriteria yang jelas tanpa dipengaruhi oleh subjektivitas penilai. Subali (2012:24) menyatakan bahwa pendidik harus melakukan penyusunan instrumen untuk dapat dijadikan pedoman dalam memberikan penilaian hasil belajar kepada peserta didik. Sementara itu, ketiadaan RPP oleh beberapa pendidik menjadikan pendidik tersebut tidak melakukan pengembangan terhadap indikator untuk dijadikan acuan dalam melakukan penilaian. Seperti yang dikatakatan Majid (2015:125) bahwa penyusunan RPP dalam penilaian autentik dimaksudkan untuk mengembangkan indikator pencapaian hasil belajar dari setiap KD yang dapat dijadikan acuan untuk melakukan penilaian.

Selanjutnya $\quad 95 \%$ dari 21 responden menyatakan tidak melakukan analisis terhadap kualitas instrumen penilaian yang dibuat. Dengan tidak melakukan analisis terhadap kualitas instrumen penilaian, pendidik tidak dapat mengetahui keakuratan instrumen yang dibuatnya. Hal tersebut menjadikan instrumen yang dibuat tidak memiliki syarat seperti yang dikemukakan Arifin 
(2009:69) yang menyatakan bahwa instrumen yang baik adalah instrumen yang valid, reliabel, relevan, representatif, praktis, spesifik, dan proporsional.

Sementara itu, untuk program tindak lanjut yang dapat diberikan pendidik dari hasil penilaian autentik dapat berupa kegiatan remedial atau pengayaan (Permendikbud Nomor 65 Tahun 2013) Dalam hasil wawancara, program tindak lanjut yang diberikan pendidik hanya berupa kegiatan remedial dan tidak semua pendidik memberikan kegiatan tersebut. Kegiatan remedial tersebut diberikan oleh $86 \%$ dari 21 responden kepada peserta didik yang dilakukan untuk memperbaiki nilai dari peserta didik yang belum mencapai KKM. Hal ini sesuai dengan yang dikatakan Sobri (2009:164) bahwa kegiatan remedial diperlukan bagi peserta didik yang belum mencapai kemampuan minimal yang ditetapkan.

Dalam pelaksanaan penilaian autentik menyediakan teknik penilaian yang beragam mencakup penilain ranah sikap, pengetahuan, dan keterampilan. Dari kelima teknik penilaian ranah sikap yakni observasi, penilaian diri, wawancara, penilaian antar teman sebaya, dan jurnal sebanyak $100 \%$ dari 21 responden menyatakan hanya melakukan pengamatan atau observasi sebagai cara dalam melakukan penilaian ranah sikap kepada peserta didik. Observasi merupakan cara yang dianggap paling objektif untuk mengetahui karakter dari masing-masing peserta didik karena dapat jelas terlihat pada saat proses pembelajaran berlangsung. Hal ini sesuai dengan pendapat Kunandar (2013:118) yang menyatakan bahwa data yang diperoleh dari hasil observasi relatiflebih objektif, karena diperoleh melalui pengamatan langsung dari pendidik.

Dalam melakukan observasi atau pengamatan kepada peserta didik dibutuhkan instrumen observasi yang berisi sejumlah indikator perilaku yang akan diamati (Majid, 2015:169). Hal ini menjadi bertentangan karena 100\% dari 21 responden menyatakan tidak melakukan penyusunan instrumen observasi, melainkan yang dilakukan hanya berdasarkan pengamatan semata tanpa adanya uraian catatan mengenai sikap peserta didik atau bukti-bukti yang autentik. Hal tersebut membenarkan hasil penelitian Wulandari (2015) yang menyatakan bahwa tidak semua pendidik membuat rangkuman yang melibatkan peserta didik sebagai bahan catatan.

Sebenarnya, dari ketiga sekolah pada akhir semester pembelajaran membagikan instrumen penilain berupa kuesioner penilaian diri. Namun, bagi beberapa pendidik teknik penilaian ini masih kurang optimal untuk menilai sikap peserta didik, karena peserta didik tersebut cenderung memilih jawaban yang paling baik untuk menilai dirinya sendiri. Serupa dengan pendapatKunandar (2013:131) yang menyatakan bahwa data yang diperoleh dari hasil penilaian diri cenderung subjektif dan memungkinkan terjadinya pengisian yang tidak jujur. Sedangkan untuk teknik penilaian lainnya seperti penilaian antar teman sebaya, wawancara, maupun jurnal, pendidik sepakat berpendapat bahwa itu merupakan tugas wali kelas dalam 
menilai secara lengkap untuk ranah sikap peserta didik.

Untuk penilaian ranah pengetahuan dari ketiga teknik penilaian yakni tes tertulis, tes lisan, dan penugasan, teknik yang paling banyak diberikan oleh pendidik yakni 100\% dari 21 responden menggunakan teknik dalam bentuk tes tertulis. Tes tertulis dirasa paling mudah bagi pendidik dalam membuat instrumen dan dalam memberikan penilaian. $\mathrm{Hal}$ tersebut sesuai dengan hasil penelitian Pantiwati (2013) yang menyatakan bahwa tes tertulis bentuk objektif mendominasi instrumen penilaian hasil belajar peserta didik karena dianggap teknik yang mudah dilaksanakan dan cepat dalam pengoreksian.

Selanjutnya, $\quad 14 \%$ dari 21 responden memberikan teknik penilaian dalam bentuk tes lisan. Tidak semua pendidik memberikan tes dalam bentuk lisan, karena pendidik beranggapan akan terjadi kesulitan bagi peserta didik dalam menjawab pertanyaan dalam bentuk lisan. Hal ini sesuai dengan hasil wawancara kepada peserta didik yang membenarkan bahwa dengan tes lisan peserta didik akan merasa kesulitan dalam memberikan jawaban. Sedangkan menurut Majid (2015:197) dengan diadakannya tes lisan ini pendidik akan lebih mengetahui kemampuan peserta didik dalam menjawab pertanyaan dan cara peserta didik mengembangkan jawabannya tersebut.

Dalam hasil wawancara juga menunjukkan bahwa $62 \%$ dari 21 responden memilih teknik penilaian ranah pengetahuan dalam bentuk penugasan berupa pekerjaan rumah.
Dengan memberikan tugas kepada peserta didik, pendidik mengganggap hal tersebut merupakan suatu latihan tambahan bagi peserta didik untuk lebih memahami tentang apa yang telah dipelajarinya. Hal ini sesuai dengan pendapat Kunandar (2013) yang menjelaskan dengan melakukan pemberian tugas kepada pesertadidik bertujuan untuk pendalaman terhadap penguasaan kompetensi pengetahuan yang telah dipelajari atau dikuasai di kelas melalui proses pembelajaran.

Untuk penilaian ranah keterampilan dari ketiga teknik penilaian yakni unjuk kerja, proyek, dan portofolio sebanyak $100 \%$ dari 21 responden menyatakan hanya menggunakan teknik penilaian unjuk kerja sebagai cara dalam melakukan penilaian ranah keterampilan pada peserta didik. Hal ini bertentangan dengan pendapat Kunandar (2013:38) yang mengemukakan bahwa dalam penilaian autentik harus menggunakan berbagai cara. Artinya, dalam melakukan penilaian terhadap peserta didik harus menggunakan beberapa teknik penilaian (disesuaikan dengan tuntutan kompetensi).

Unjuk kerja yang dilakukan pendidik untuk menilai keterampilan peserta didik pun beragam, seperti unjuk kerja dalam mempresentasikan suatu bahasan untuk menilai keterampilan peserta didik dalam menjelaskan materi dan bagaimana cara peserta didik tersebut menjawab apabila ada teman yang memberikan pertanyaan, unjuk kerja dalam mempraktikan suatu materi ajar untuk menilai keterampilan seberapa baik peserta didik tersebut menyelesaikan 
praktik tersebut, dan dapat pula dilakukan unjuk kerja dalam pengumpulan pada tugas yang diberikan dengan seberapa cepat peserta didik tersebut dapat menyelesaikan dan menjawab tugas dengan baik dan benar. Hal ini serupa dengan pendapat Marzano (1993) dalam Pantiwati (2013) yang mengemukakan bahwa unjuk kerja merupakan cara penilaian yang dianggap lebih autentik dibanding dengan bentuk lain, karena dapat memberikan suatu sarana yang efektif dalam mengukur kemampuan peserta didik yang sebenarnya.

\section{Dalam penerapan penilaian} autentik sebanyak $86 \%$ dari 21 responden menyatakan menemukan kendala pada saat menerapan penilaian autentik kepada peserta didik. Kendala yang umumnya dinyatakan oleh responden, terdapat pada kurangnya waktu dalam melakukan penilaian. Kendala tersebut sesuai dengan hasil penelitian Maryam (2014:76) yang menyatakan bahwa waktu yang tidak mencukupi menjadi penyebab pendidik mengalami kesulitan dalam penerapan penilaian autentik.

Keterbatasan waktu tersebut dikarenakan dalam penilaian autentik membutuhkan banyak komponen atau aspek yang harus dinilai oleh pendidik. Hal tersebut disebabkan dari karakteristik penilaian autentik itu sendiri yang harus dilakukan secara berkelanjutan dan pada tiap proses pembelajaran. Serupa dengan pendapat Basuki dan Hariyanto (2012:171) yang mengemukakan tentang karakteristik penilaian autentik yang harus dilakukan secara berkesinambungan dan terintegrasi. Artinya, dalam melakukan penilaian autentik harus secara berkesinambungan (terus menerus) dan merupakan satu kesatuan secara utuh sebagai alat untuk mengumpulkan informasi terhadap pencapaian kompetensi peserta didik. Namun, menurut para pendidik waktu mengajar sudah akan habis untuk menjelaskan materi pelajaran kepada peserta didik sehingga terkadang dalam satu pertemuan tidak sempat untuk melakukan penilaian.

\section{KESIMPULAN DAN SARAN}

Berdasarkan hasil penelitian dan pembahasan maka dapat diambil kesimpulan bahwa penerapan penilaian autentik berdasarkan kurikulum 2013 pada kompetensi keahlian Teknik Gambar Bangunan di SMK Negeri wilayah DKI Jakarta belum berjalan dengan baik. Hal tersebut disebabkan karena banyaknya kendala yang dihadapi oleh pendidik dalam penerapan penilaian autentik antara lain: (1) Kurangnya pemahaman pendidik terhadap penilaian autentik; (2) Pendidik tidak terbiasa membuat instrumen ranah sikap dan ranah keterampilan sehingga penilaian berlangsung tanpa adanya instrumen tersebut; (3) Kurangnya waktu dalam melakukan penilaian autentik selama proses pembelajaran; (4) Kurangnya diadakan pelatihan secara menyeluruh bagi pendidik yang mengajar mata pelajaran kelompok $\mathrm{C}$ (kejuruan) tentang penilaian autentik. 


\section{Implikasi}

Berdasarkan hasil penelitian, tindak lanjut yang dapat diberikan adalah sebagai berikut:

Penerapan penilaian autentik berdasarkan kurikulum 2013 akan lebih baik jika pendidik dapat memahami dengan benar tentang penilaian autentik, sehingga prosedur dalam pelaksanaan penilaian autentik dapat terpenuhi secara lengkap.

3. Penerapan penilaian autentik akan lebih optimal jika dari pihak sekolah rutin melakukan pengawasan, agar penerapan penilaian autentik yang dilakukan pendidik akan terus berjalan dengan baik.

4. Penilaian autentik akan lebih baik jika pendidik dapat melaksanakannya secara berkesinambungan (terusmenerus), sehingga informasi pencapaian kompetensi dari masingmasing peserta didik dapat diketahui dengan jelas.

5. Penilaian autentik akan lebih bermanfaat jika dalam penerapannya pendidik benar- benar menilai secara keseluruhan mulai dari sikap, pengetahuan, dan keterampilan, agar peserta didik dapat meningkatkan kemampuannya bukan hanya pada ranah pengetahuan melainkan sikap dan keterampilan.

\section{Saran}

Adapun saran yang dapat disampaikan pada hasil penelitian ini antara lain:

5. Sebelum melakukan proses pembelajaran pendidik sebaiknya menyusun Rencana Program
Pembelajaran (RPP) agar proses pembelajaran dapat berlangsung secara sistematis.

6. Selain menyusun RPP pendidik juga sebaiknya menyusun instrumen penilaian beserta pedoman penilaian agar dalam pelaksanaan penilaian benar- benar dapat menggambarkan kompetensi yang harus dicapai oleh peserta didik.

7. Pendidik juga perlu melakukan analisis kualitas terhadap instrumen yang telah dibuat, agar instrumen tersebut benar-benar dapat mengukur kemampuan yang dimiliki peserta didik.

8. Dengan ditemukannya kendala dalam masalah waktu pelaksanaan penilaian autentik serta pemahaman pendidik yang masih kurang tentang penilaian autentik, perlu kiranya dari pihak sekolah mengadakan pelatihan bagi seluruh pendidik mata pelajaran kelompok $C$ (kejuruan) untuk lebih memahami dan membuat perangkat penilaian autentik agar penilaian autentik dapat berjalan dengan baik.

\section{DAFTAR PUSTAKA}

Ameliyana, Novi. 2014. Persepsi Guru Teknik Gambar Bangunan tentang Kurikulum 2013: Studi Analisis Deskriptif pada SMK Negeri di DKI Jakarta.

Jakarta: Skripsi Fakultas Teknik Universitas Negeri Jakarta.

Arifin, Zaenal. 2009. Evaluasi Pembelajaran: Prinsip, Teknik, dan Prosedur. Bandung: PT. Remaja Rosdakarya. 
Basuki, Ismet. \& Hariyanto. 2012. Asesmen Penelitian. Bandung: PT. Remaja Rosdakarya.

Djali. \& Muljono, Pudji. 2008. Pengukuran dalam Bidang Pendidikan. Jakarta: PT. Grasindo.

Endang, Purwanti. 2008. Assesment Pembelajaran SD. Jakarta: Depdiknas.

Enggarwati, Nur. 2015. Kesulitan Guru SD Negeri Glagah dalam Mengimplementasikan Penilaian Autentik pada Kurikulum 2013. Yogyakarta: Skripsi Fakultas IImu Pendidikan Universitas Negeri Yogyakarta.

Hamalik, Oemar. 2014. Kurikulum dan Pembelajaran. Jakarta: PT. Bumi Aksara.

Kemdikbud. 2013. Pedoman Penilaian Hasil Belajar. Jakarta: Kemdikbud.

Kunandar. 2013. Penilaian Autentik (Penilaian Hasil Belajar Peserta Didik Berdasarkan Kurikulum 2013) Suatu Pendekatan Praktis Disertai dengan Contoh. Jakarta: PT. Rajagrafindo Persada.

Kusmijati, Neneng. 2014. Penerapan Penilaian Autentik Sebagai Upaya Memotivasi Belajar Peserta Didik. Prosiding Seminar Nasional Hasil Penelitian dan Pengabdian LPPM UMP. Purwokerto: 20 Desember 2014.

Majid, Abdul. 2015. Penilaian Autentik Proses dan Hasil Belajar. Bandung: PT. Remaja Rosdakarya.
Mardapi, Djemari. 2012. Pengukuran Penilaian \& Evaluasi Pendidikan. Yogyakarta: Nuha Medika.

Maryam, Siti. 2014. Penerapan Penilaian Otentik dalam Pembelajaran Bahasa Indonesia. Skripsi: Fakultas Bahasa dan Seni Universitas Negeri Yogyakarta.

Muchtar, Hartati. 2010. Penerapan Penilaian Autentik dalam Upaya Peningkatan Mutu Pendidikan. Jurnal Pendidikan Penabur, 14:68-76.

Mulyasa. 2013. Pengembangan dan Implementasi Kurikulum 2013. Bandung: PT. Remaja Rosdakarya.

Murti, Kuntari. 2015. Pendidikan Abad 21 dan Implementasinya pada Pembelajaran di Sekolah Menengah Kejuruan (SMK) untuk Paket Keahlian Desain Interior. Artikel Kurikulum 2013 SMK.

Muslich, Masnur. 2011. Autentic Assessment: Penilaian Berbasis Kelas dan Kompetensi. Bandung: PT. Refika Aditama.

Nurgiyantoro, Burhan. 2011. Penilaian otentik dalam pembelajaran Bahasa. Yogyakarta: Gajah Mada University Press.

Nurhadi. 2004. Pembelajaran Kontektual dan Penerapannya dalam KBK. Malang: Universitas Negeri Malang.

Pantiwati, Yuni. 2013. Hakekat Asesmen Autentik dan Penerapannya dalam Pembelajaran Biologi. Jurnal 
Edukasi Matematika dan Sains, 1:18-27.

Peraturan Menteri Pendidikan dan Kebudayaan Republik Indonesia Nomor 65 Tahun 2013 tentang Standar Proses Pendidikan Dasar dan Menengah.

Peraturan Menteri Pendidikan dan Kebudayaan Republik Indonesia Nomor 66 Tahun 2013 tentang Standar Penilaian Pendidikan.

Peraturan Menteri Pendidikan dan Kebudayaan Republik Indonesia Nomor 70 Tahun 2013 tentang Kerangka Dasar dan Struktur Kurikulum Sekolah Menengah Kejuruan/Madrasah Aliyah Kejuruan.

Peraturan Menteri Pendidikan dan Kebudayaan Republik Indonesia Nomor 104 Tahun 2014 tentang Penilaian Hasil Belajar oleh Pendidik pada Pendidikan Dasar dan Pendidikan Menengah.

Peraturan Pemerintah Nomor 32 tahun 2013 tentang Standar Nasional Pendidikan.

Pusat Kurikulum, Balitbang. 2009. Kurikulum Tingkat Satuan Pendidikan. Jakarta: Depdiknas.

Puspitasari, Diana. 2015. Penerapan Penilaian Autentik dala Pembelajaran Sejarah pada
Kurikulum 2013 di SMK Negeri 1

Bawen Tahun 2014/2015.

Semarang: Skripsi Fakultas IImu Sosial Universitas Negeri Semarang.

Ratnawulan, Elis. \& Rusdiana. 2015. Evaluasi Pembelajaran. Bandung: CV. Pustaka Setia.

Subali, Bambang. 2012. Prinsip Asesmen \& Evaluasi Pembelajaran. Yogyakarta: UNY Press.

Sugiyono. 2012. Metode Penelitian Kuantitatif Kualitatif dan $R \& D$. Bandung: Alfabeta.

Surapranata, Sumarna. \& Hatta, Mohammad. 2006. Penilaian Berbasis Kelas Penilaian Portofolio Implementasi Kurikulum 2004. Bandung: PT. Remaja Rosdakarya.

Sobri, Sutikno. 2009. Belajar dan Pembelajaran. Bandung: Prospect.

Undang-undang Nomor 20 tahun 2003 tentang Sistem Pendidikan Nasional.

Wulandari, Annisa. 2015. Evaluasi Implementasi Model Penilaian Autentik dalam Penilaian Kurikulum 2013 di SMK Negeri 1 Banyudono. Semarang: Fakultas IImu Pendidikan Universitas Negeri Semarang. 